\title{
Fine structure of Henneguya hemiodopsis sp. n. (Myxozoa), a parasite of the gills of the Brazilian teleostean fish Hemiodopsis microlepes (Hemiodontidae)
}

\author{
Carlos Azevedo ${ }^{1 /+}$, Graça Casal ${ }^{2,3}$, Ivete Mendonça ${ }^{4}$, Edilson Matos ${ }^{5}$ \\ ${ }^{1}$ Department of Cell Biology, Institute of Biomedical Sciences ${ }^{2}$ Laboratory of Pathology, Centre for Marine and Environmental Research, \\ University of Porto, Porto, Portugal ${ }^{3}$ Departamento de Ciências, Instituto Superior de Ciências da Saúde-Norte, Gandra, Portugal \\ ${ }^{4}$ Laboratório de Saúde Animal, Universidade Federal do Piauí, Teresina, PI, Brasil ${ }^{5}$ Laboratório de Pesquisa Carlos Azevedo, Universidade \\ Federal Rural da Amazônia, Belém, PA, Brasil
}

A fish-infecting myxosporean, Henneguya hemiodopsis sp. n., found infecting the gills of Hemiodopsis microlepis and collected from the Poty River near the city of Teresina, Brazil, was described based on ultrastructural studies. The parasite occurred within large whitish polysporic plasmodia (up to $200 \mu \mathrm{m}$ in diameter) containing asynchronous developmental sporogonic stages, mainly mature spores. The spores measured $19.7 \pm 0.9 \mu \mathrm{m}$ in total length $(n=$ 30) and the ellipsoidal spore body was $10.8 \pm 0.5 \mu \mathrm{m}$ long, $3.3 \pm 0.4 \mu \mathrm{m}$ wide and $2.5 \pm 0.5 \mu \mathrm{m}$ thick. The spores were composed of two equal shell valves adhering together along the straight suture line, with each valve having equalsized caudal tapering tails measuring $8.7 \pm 0.6 \mu \mathrm{m}$ in length. The spores were surrounded by a thin anastomosed network of microfibrils, more evident on the tails. There were two symmetric elongated bottle-like polar capsules 3.5 $\pm 0.3 \mu \mathrm{m}$ long and $1.0 \pm 0.2 \mu \mathrm{m}$ wide, each with a polar filament with five to six coils. Given the morphological and ultrastructural differences from previously described parasites and the specificity of the host species, we propose a new species, named $\mathrm{H}$. hemiodopsis $s p$. $n$.

Key words: ultrastructure - Henneguya hemiodopsis sp. n. - Myxozoa - parasite - gill - Brazilian fish

The South American Continent contains one of the biggest hydrographic networks in the world, in which a great variety of ictiofauna species reside. Since the first description of Henneguya Thélohan, 1892 (Lom \& Dyková 2006), the second largest genus of the Myxobolidae family, many species have been reported, mainly parasitising freshwater fishes throughout the world. However, the number of myxozoan parasites described from Brazil is very low, especially considering that the country has one of the most diverse freshwater fish populations in the world with about 8,000 species (Cellere et al. 2002). Thirty-six species have been described from Brazilian fauna based on light microscopy micrographs and diagrammatic illustrations (Jakowska \& Nigrelli 1953, Kent \& Hoffman 1984, Gioia et al. 1986, Martins et al. 1988, Gioia \& Cordeiro 1996, Martins \& Souza 1997, Barassa et al. 2003a, b, Eiras et al. 2004a, b, 2008, 2009, Martins \& Onaka 2006, Abdallah et al. 2007). Recently, ultrastructural studies of developmental stages and mature spores supported the classification of some new species of the genus Henneguya (Rocha et al. 1992, Azevedo

Financial support: Eng. A Almeida Foundation (Porto, Portugal), CNPq, CAPES

+ Corresponding author: azevedoc@icbas.up.pt

Received 2 April 2009

Accepted 17 June 2009
\& Matos 1995, 1996, 2002, 2003, Azevedo et al. 1997, 2008, Casal et al. 1997, 2003, Vita et al. 2003, Adriano et al. 2005, Matos et al. 2005).

In the present paper, we report light and electron microscopy-based data on the mature spores of a new parasite, designated herein as Henneguya hemiodopsis sp. n., infecting the gills of a teleostean fish of some economic importance found in a river in North-Eastern Brazil.

\section{MATERIALS AND METHODS}

Fifty specimens (18 males and 32 females) of the freshwater teleost Hemiodopsis microlepis Kern, 1858 (Teleostei: Characiformes: Hemiodontidae)(Braziliancommon name flexeiro, , endemic to this region, were recently collected from the Poty River $\left(05^{\circ} 05^{\prime} \mathrm{S} 42^{\circ} 48^{\prime} \mathrm{W}\right)$ near the city of Teresina [state of Piauí (PI)], Brazil. The fish were lightly anaesthetised with MS 222 (Sandoz Laboratories) and dissected and the gills, containing several whitish cysts (cyst-like plasmodia), were removed from the gill lamellae and examined with a light microscope equipped with Nomarski interference-contrast (DIC) optics.

For ultrastructural studies, small fragments of the gill lamellae containing cyst-like plasmodia were excised and fixed in $3 \%$ glutaraldehyde in $0.2 \mathrm{M}$ sodium cacodylate buffer ( $\mathrm{pH} 7.2$ ) at $4^{\circ} \mathrm{C}$ for $10 \mathrm{~h}$. After being rinsed overnight in the same buffer at $4^{\circ} \mathrm{C}$ and postfixed in $2 \%$ osmium tetroxide in the same buffer for $3 \mathrm{~h}$ at $4^{\circ} \mathrm{C}$, the fragments were dehydrated through an ascending ethanol series followed by propylene oxide and embedded in Epon. Semi-thin sections were stained with methylene blue-Azure II and observed by DIC optics. Ultra-thin sections were double-stained with aque- 
ous uranyl acetate and lead citrate and observed under a JEOL 100CXII transmission electron microscope (TEM) operated at $60 \mathrm{kV}$.

\section{RESULTS}

Of the 50 adult specimens of $H$. microlepis (Teleostei: Hemiodontidae) examined, 32 (64\%) contained gills parasitised by an organism identified as follows: Phylum Myxozoa Grassé, 1970; Class Myxosporea Bütschli, 1881; Order Bivalvulida Shulman, 1959; Family Myxobolidae Thélohan, 1892; genus Henneguya Thélohan, 1892, according to the classification proposed by Lom and Dyková (2006).

The morphological and ultrastructural data, mainly the shape and dimension of the spores and polar capsules (PC), as well as the polar filament coils and arrangement, indicate that this parasite is a new species, herein named $H$. hemiodopsis.

For description of the plasmodium and mature spores, light microscopy (DIC) (Figs 1-3), TEM (Figs 4-12) and a schematic drawing (Fig. 13) were used.

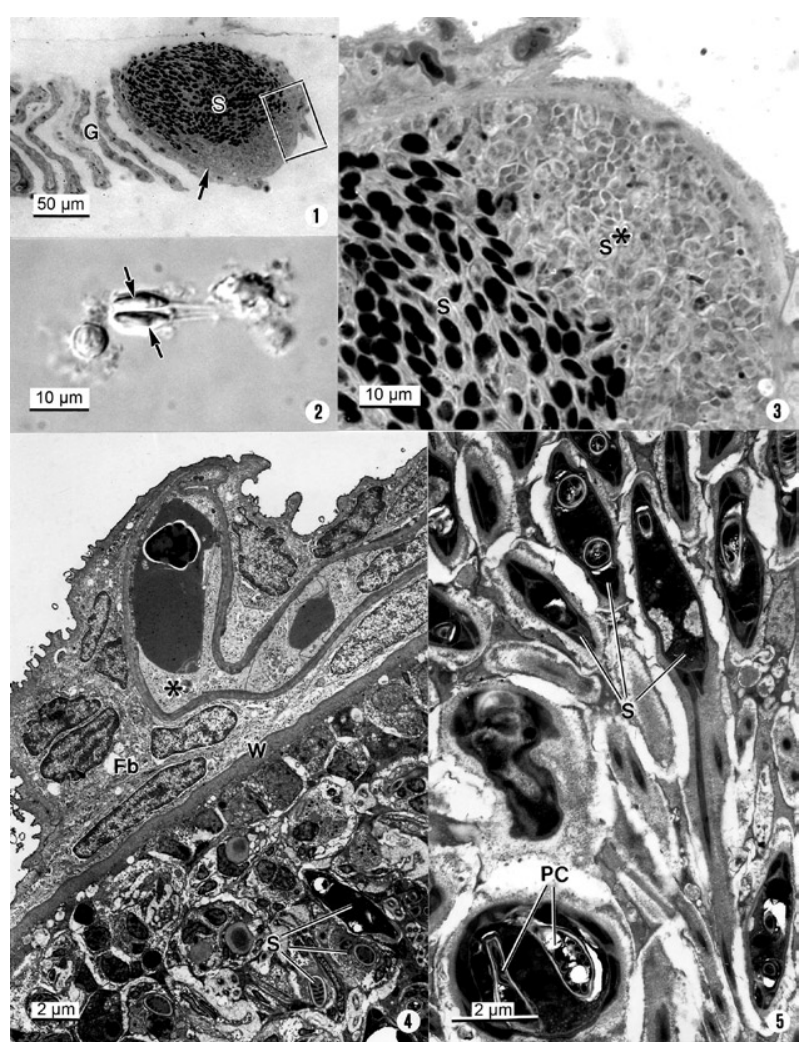

Figs 1-5: light and transmission electron micrographs of Henneguya hemiodopsis n.sp. 1: semithin section of a plasmodium in close contact with the gill filaments $(\mathrm{G})$ containing numerous mature spores (S) and a group of immature spores (arrows); 2: two free fresh spores (arrows) observed in DIC; 3: magnification of the boxed area in Fig. 1 showing the plasmodium periphery surrounding numerous mature (S) and immature spores ( $\left.\mathrm{S}^{*}\right)$; 4: ultrastuctural details of the plasmodium periphery showing the wall (W) in the close contact with the gill cell of a filament, where some fibroblasts $(\mathrm{Fb})$ and a blood vessel are visible $(*)$. Internally several spore sections (S) are observed; 5 : ultrathin sections of several spores (S) sectioned at different levels showing the sections of the polar capsules (PC).

\section{H. hemiodopsis sp. $\mathrm{n}$.}

(Figs 1-3)

Description - Vegetative stages: whitish roundshaped polysporic plasmodia (cyst-like plasmodia), measuring up to $200 \mu \mathrm{m}$ contained numerous mature and immature spores, indicating asynchronous development (Figs 3 , 4). The plasmodium wall was formed by a dense material that was in contact with the epithelial gill cells. The zone of contact contained several fibroblasts, collagen fibrils and some capillaries (Fig. 4). The spores were ellipsoidal with a total length of $19.7 \pm 0.9 \mu \mathrm{m}(\mathrm{n}=30)$, body length $10.8 \pm 0.5 \mu \mathrm{m}(\mathrm{n}=20)$, body width (frontal view) $3.3 \pm 0.4 \mu \mathrm{m}(\mathrm{n}=20)$ and body thickness (side view) $2.5 \pm 0.5 \mu \mathrm{m}(\mathrm{n}=15)$. The two valves were symmetrical and thin and each was prolonged by a tapering tail $8.7 \pm 0.6 \mu \mathrm{m}(\mathrm{n}=20)$ long (Figs 2, 5-7). Elongated bottle-like PC localised side by side in the anterior pole of the spore were equal in size, measuring $3.5 \pm 0.3 \mu \mathrm{m}$ in length $(\mathrm{n}=25)$ by $1.0 \pm 0.2 \mu \mathrm{m}(\mathrm{n}=25)$ in width (Figs 6-9). The apical pore of the bottle-like PC was closed by a dense stopper and an electron-dense ring surrounded the neck of the bottle-like PC. The neck of the bottle-like PC measured $1.7 \pm 0.4 \mu \mathrm{m}(\mathrm{n}=12)$ in length and $\sim 0.5 \mu \mathrm{m}$ in diameter (Figs 8-10). Inside the PC, the isofilar polar filament was coiled with 5-6 turns oblique to the longitudinal axis (Figs 8,9). The internal matrix of the polar filaments was denser than the surrounding matrix of the PC (Figs 8,9). The spores presented numerous ramified and anastomosed microfibrils at the surface (Figs 9-11), more evident in the tails (Figs 6, 7, 12).

Type host - H. microlepis Kner, 1858 (Teleostei: Characiformes: Hemiodontidae) (12-17 cm in length on average).

Site of infection: whitish cysts (cyst-like plasmodia) were found in secondary gill lamellae.

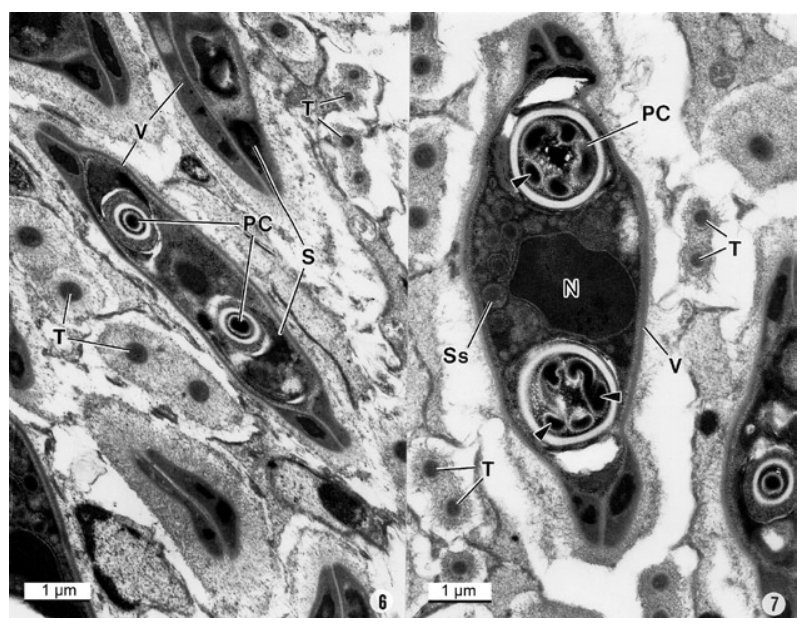

Figs 6, 7: transmission electron micrographs of Henneguya hemiodopsis n.sp. 6: some spores (S) sectioned at different levels, one of which in transverse section showing the two polar capsules (PC). The shell valves $(\mathrm{V})$ and the tails $(\mathrm{T})$ are observed; 7: a transverse section of a spore at PC levels showing the shell valves (V), polar filament coil sections (arrowheads), one of the two nuclei (N) and sporoplasmosomes (Ss). Some tail sections (T) are visible near the spores. 


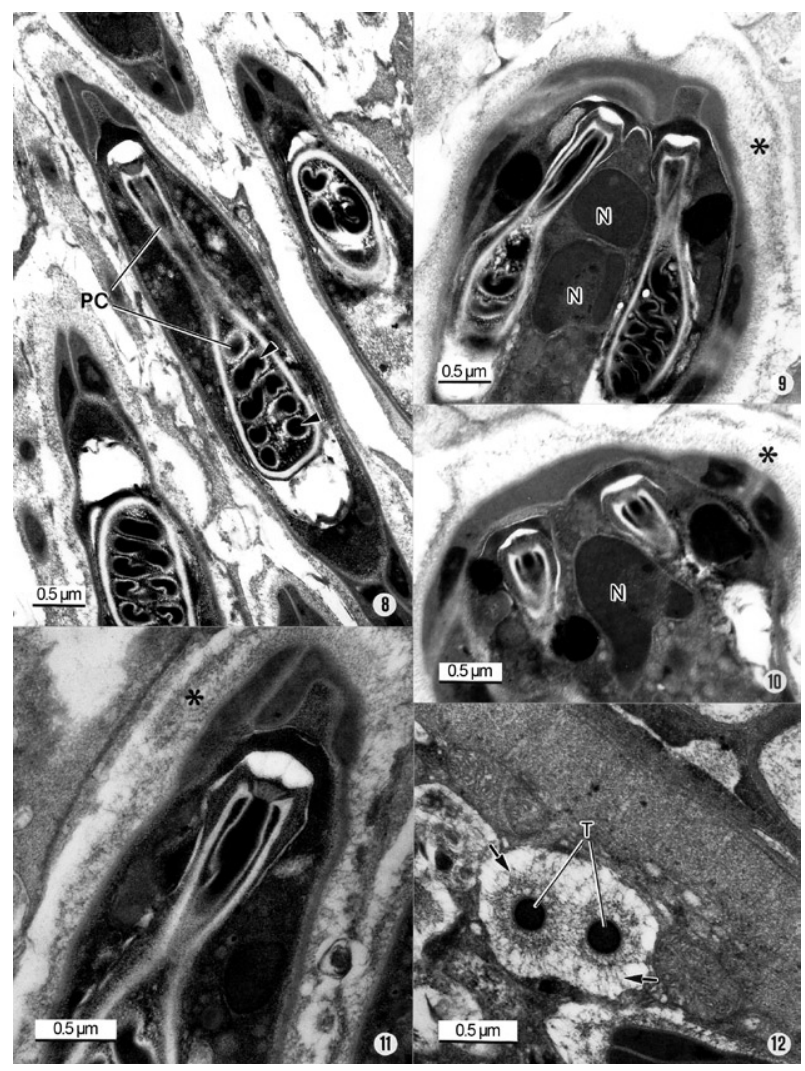

Figs 8-12: transmission electron micrographs of Henneguya hemiodopsis n.sp. 8: ultrastructural detail of a longitudinal section of a polar capsule (PC) showing the morphology of the capsule and the organization of the polar filament coils (arrowheads). Just near the spore another PC showing the coils of a filament tangentially sectioned. 9: longitudinal section of the anterior portion of a spore showing the position of the two nuclei $(\mathrm{N})$ located between the PC. The shell valves show a surrounding network of anastomosed microfibrils $(*) ; 10,11$ : two ultrastructural details of the complex organization of the apical region of the PC and a nucleus $(\mathrm{N})$. The valves show a network of anastomosed microfibrils $\left.{ }^{*}\right)$; 12: detail of the transverse sections of two tails (T) showing the surrounding network of anastomosed microfibrils (arrow).

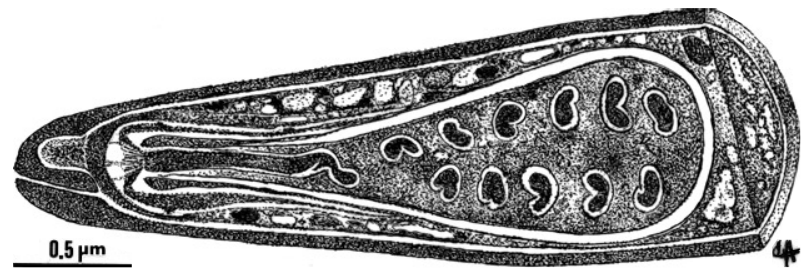

Fig. 13: semischematic drawing of a longitudinal section of a polar capsule (PC) with their filament coil sections showing the elongated bottle-like form of the PC.

Prevalence and intensity - Thirty-two out of 50 (18 males and 32 females) adult fish (64\%) were parasitised, with similar rates in both sexes.

Type locality - Poty River $\left(05^{\circ} 05^{\prime} \mathrm{S} 42^{\circ} 48^{\prime} \mathrm{W}\right)$, near the city of Teresina (PI).
Type data and depository - A glass slide containing semi-thin sections of mature spores of the hapantotype was deposited in the International Protozoan Type Slide Collection at the Smithsonian Institution Washington, DC 20560, USA, with acquisition USNM 1123997.

Etymology - The specific epithet derives from the generic name of the host (Hemiodopsis).

Histopathology - Our observations showed that the infected gill lamellae were associated with an increased number of fibroblasts just near the zone of contact of the epithelial gill with the wall of the cyst-like plasmodia, with local atrophy and deformation of the gill lamellae (Fig. 4).

\section{DISCUSSION}

The morphology of the myxosporean described in the present paper has the distinguishing features of the genus Henneguya Thélohan, 1899 (i.e., ellipsoidal spore body formed by two shell valves, each with an elongated tail and two PC internally) (Lom \& Dyková 2006). The morphological and ultrastructural aspects of the mature spores, as well as the host specificity and localization of the infection with this parasite, were compared to those of other myxosporidian species of the genus Henneguya from different geographical areas, mainly species that parasitise Brazilian freshwater fishes.

Recently, 34 valid Henneguya species described from Brazilian fish were summarised in a table containing the spore measurements (Eiras et al. 2008). Two new species, more recently described, must be added to this number: Henneguya rondoni, described on the basis of ultrastructural data (Azevedo et al. 2008) and Henneguya corruscan, described based on light micrographs and a drawing (Eiras et al. 2009).

Comparing the morphology and the dimensions of the spores of these species, we observe that $H$. hemiodopsis sp. n. differs mainly in the shape and size of the body, tails and PC as well as in the arrangement of the polar filament coils. All of the previously described species have different morphological characteristics and host specificity compared to the presently described species.

On the other hand, the presence of an external adherent sheath surrounding the spore body wall and tails has been used as an important morphological taxonomic characteristic to distinguish Henneguya spp. Taking into account this structure, we summarise in Table the spore measurements of Henneguya spp, whose spores are surrounded by a sheath.

Compared to the proposed new species $(H$. hemiodopsis), several differences were observed in the external sheath of other Henneguya spp that contain this structure (Table). Whereas in H. hemiodopsis sp. n. the spores were surrounded by a thin anastomosed network of microfibrils, in Henneguya theca, Henneguya adherens, Henneguya testicularis, Henneguya rhamdia and $H$. rondoni, the spores were surrounded by a hyaline homogenous structure and in Henneguya malabarica and Henneguya striolata, the sheath was constituted by granulo-fibrilar structures organised into a complex ramified network. 


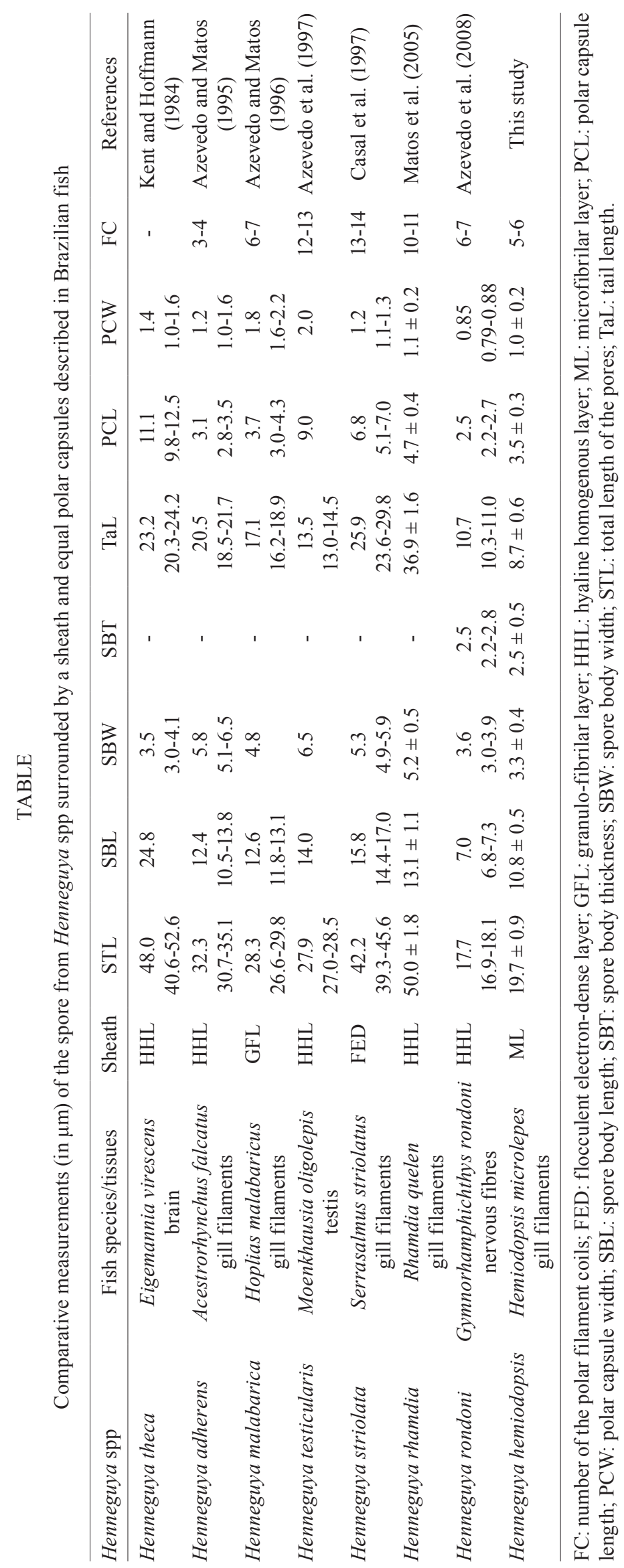


This inflammatory reaction seems to be of the same type as that observed and described in other Brazilian fishes (Martins et al. 1988, Adriano et al. 2005).

In conclusion, on the basis of the morphological differences in the size and shape of the spore and PC and the number and arrangement of the polar filament coils, we think that there are sufficient arguments for the establishment of a new species, named H. hemiodopsis sp. n.

\section{ACKNOWLEDGMENTS}

To the technical assistance of Joana Carvalheiro and João Carvalheiro.

\section{REFERENCES}

Abdallah VD, Azevedo RK, Luque JL, Bomfim TCB 2007. Two new species of Henneguya Thélohan, 1892 (Myxozoa, Myxobolidae), parasitic on the gills of Hoplosternum littorale (Callichthyidae) and Cyphocharax gilbert (Curimatidae) from the Guandu River, state of Rio de Janeiro, Brazil. Parasitol Latinoam 62: 35-41.

Adriano EA, Arana S, Cordeiro NS 2005. Histopathology and ultrastructure of Henneguya caudalongula sp. n. infecting Prochilodus lineatus (Pisces: Prochilodontidae) cultivated in the state of São Paulo, Brazil. Mem Inst Oswaldo Cruz 100: 177-181.

Azevedo C, Casal G, Matos P, Matos E 2008. A new species of Myxozoa, Henneguya rondoni n.sp. (Myxozoa), from the peripheral nervous system of the Amazonian fish, Gymnorhamphichthys rondoni (Teleostei). J Eukaryot Microbiol 55: 229-234.

Azevedo C, Corral L, Matos E 1997. Light and ultrastructural data on Henneguya testicularis n.sp. (Myxozoa, Myxobolidae), a parasite from the testis of the Amazonian fish Moenkhausia oligolepis. Syst Parasitol 37: 111-114.

Azevedo C, Matos E 1995. Henneguya adherens sp. n. (Myxozoa, Myxosporea), parasite of the Amazonian fish, Acestrorhynchus falcatus. J Eukaryot Microbiol 42: 515-518.

Azevedo C, Matos E 1996. Henneguya malabarica sp. nov. (Myxozoa, Myxobolidae) in the Amazonian fish Hoplias malabaricus. Parasitol Res 82: 222-224.

Azevedo C, Matos E 2002. Fine structure of the myxosporean, Henneguya curimata n.sp., parasite of the Amazonian fish, Curimata inormata (Teleostei, Curimatidae). J Eukaryot Microbiol 49: 197-200.

Azevedo C, Matos E 2003. Fine structure of Henneguya pilosa sp. n. (Myxozoa: Myxosporea), parasite of Serrasalmus altuvei (Characidae), in Brazil. Folia Parasitol 50: 37-42.

Barassa B, Adriano EA, Arana S, Cordeiro NS 2003a. Henneguya curvata sp. n. (Myxosporea: Myxobolidae) parasitizing the gills of Serrasalmus spilopleura (Characidae: Serrasalminae), a South American freshwater fish. Folia Parasitol 50: 151-153.

Barassa B, Cordeiro NS, Arana S 2003b. A new species of Henneguya, a gill parasite of Astyanax altiparanae (Pisces: Characidae) from Brazil, with comments on histopathology and seasonality. Mem Inst Oswaldo Cruz 98: 761-765.

Casal G, Matos E, Azevedo C 1997. Some ultrastructural aspects of Henneguya striolata sp. nov. (Myxozoa, Myxosporea), a parasite of the Amazonian fish Serrasalmus striolatus. Parasitol Res 83: 93-95.

Casal G, Matos E, Azevedo C 2003. Light and electron microscopic study of the myxosporean, Henneguya friderici $\mathrm{n}$. sp. from the Amazonian telostean fish, Leporinus friderici. Parasitology 126: 313-319.

Cellere EF, Cordeiro N, Adriano ES 2002. Myxobolus absonus sp. n. (Myxozoa: Myxosporea) parasitizing Pimelodus maculatus (Siluriformes: Pimelodidae), a South American freshwater fish. Mem Inst Oswaldo Cruz 97: 79-80.
Eiras JC, Malta JC, Varela A, Pavanelli GC 2004a. Henneguya schizodon n. sp. (Myxozoa, Myxobolidae), a parasite of the Amazonian teleost fish Schizodon fasciatus (Characiformes, Anostomidae). Parasite 11: 169-173.

Eiras JC, Pavanelli GC, Takemoto RM 2004b. Henneguya paranaensis sp. n. (Myxozoa, Myxobolidae) a parasite of the teleost fish Prochilodus lineatus (Characiformes, Prochilodontidae) from the Paraná River, Brazil. Bull Eur Ass Fish Pathol 24: 308-311.

Eiras JC, Takemoto RM, Pavanelli GC 2008. Henneguya caudicula n. sp. (Myxozoa, Myxobolidae) a parasite of Leporinus lacustris (Osteichthyes, Anostomidae) from the high Paraná River, Brazil, with a revision of Henneguya spp infecting South America fish. Acta Protozool 47: 149-154.

Eiras JC, Takemoto RM, Pavanelli GC 2009. Henneguya corruscans n. sp. (Myxozoa, Myxosporea, Myxobolidae), a parasite of Pseudoplatystoma corruscans (Osteichthyes, Pimelodidae) from the Paraná River, Brazil: a morphological and morphometric study. Vet Parasitol 159: 154-158.

Gioia I, Cordeiro NS 1996. Brazilian myxosporidians' check-list (Myxozoa). Acta Protozool 35: 137-149.

Gioia I, Cordeiro NS, Artigas PT 1986. Henneguya intracornea $\mathrm{n}$. sp. (Myxozoa: Myxosporea) parasita do olho do lambari, Astyanax scabripinnis (Jenyns, 1842) (Osteichthyes, Characidae). Mem Inst Oswaldo Cruz 82: 19.

Jakowska S, Nigrelli RF 1953. The pathology of myxosporidiosis in the electric eel, Electrophorus electricus (Linnaeus), caused by Henneguya visceralis and Henneguya electrica spp nov. Zoologica 38: 183-191.

Kent ML, Hoffman GL 1984. Two new species of Myxozoa, Myxobolus inaequus sp. $\mathrm{n}$. and Henneguya theca sp. $\mathrm{n}$. from the brain of a South American knife fish, Eigemannia virescens (V.). J Protozool 31: 91-94.

Lom J, Dyková I 2006. Myxozoan genera: definition and notes on taxonomy, life-cycle terminology and pathogenic species. Folia Parasitol 53: 1-36.

Martins ML, Onaka EM 2006. Henneguya garavelli n. sp. and Myxobolus peculiaris n. sp. (Myxozoa: Myxobolidae) in the gills of Cyphocharax nagelli (Osteichthyes: Curimatidae) from Rio do Peixe Reservoir, São José do Rio Pardo, São Paulo, Brazil. Vet Parasitol 137: 253-261.

Martins ML, Souza VN 1997. Henneguya piaractus n. sp. (Myxozoa: Myxobolidae), a gill parasite of Piaractus mesopotamicus Holmberg, 1887 (Osteichthyes: Characidae), in Brazil. Rev Bras Biol 57: 239-245.

Martins ML, Souza VN, Moraes JRE, Moraes JRE 1988. Gill infection of Leporinus macrocephalus Garavello \& Britski, 1988 (Osteichthyes: Anostomidae) by Henneguya leporinicola n. sp. (Myxozoa: Myxobolidae). Description, histopatology and treatement. Rev Bras Biol 59: 527-534.

Matos E, Tajdari J, Azevedo C 2005. Ultrastructural studies of Henneguya rhamdia $\mathrm{n}$. sp. (Мyxoxoa) a parasite from the Amazon teleost fish, Rhamdia quelen (Pimelodidae). J Eukaryot Microbiol 52: 532-537.

Rocha E, Matos E, Azevedo C 1992. Henneguya amazonica n. sp. (Myxozoa, Myxobolidae) parasitizing the gills of Crenicichla lepidota Heckel, 1840 (Teleostei, Cichlidae) from the Amazon River. Europ J Protistol 28: 273-278.

Vita P, Corral L, Matos E, Azevedo C 2003. Ultrastructural aspects of the myxosporean Henneguya astyanax n. sp. (Myxozoa: Myxobolidae) parasite of the Amazonian teleost Astyanax keithi (Characidae). Dis Aquat Org 53: 55-60. 